\title{
Investigation of zoonotic helminths in children's playgrounds in Sivas province
}

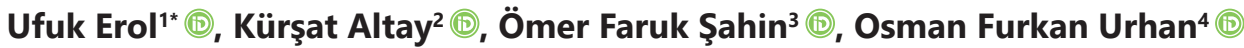 \\ 1,2,3 Department of Parasitology, Faculty of Veterinary Medicine, University of Sivas Cumhuriyet, Sivas, Turkey. \\ ${ }^{4}$ General Directory Meat and Milk Board, Sivas Meat Processing Plant, Sivas, Turkey.
}

Geliş Tarihi / Received: 23.09.2021, Kabul Tarihi / Accepted: 26.10.2021

\begin{abstract}
Human toxocariasis is categorized as a neglected parasitic disease by the Center for Disease Control and Prevention (CDC). The disease is more prevalent in children than adults because children are more frequently exposed to the eggs of $T$. canis and T. cati which are the etiological agents of human toxocariasis during playing outside. This study aimed to research the presence of helminth species in children's playgrounds in Sivas using microscopic and molecular techniques. For this purpose, 84 sand samples were taken from 25 children's playgrounds from July 2020 to July 2021. Moreover, 68 stool samples that belong to cats, dogs, and red foxes were collected from and around children's playgrounds. Toxocara spp. eggs were found in five sand samples in this study. According to PCR results, $T$. cati was detected in three sand samples while T. canis was found in two sand samples. Toxascaris leonina was detected only in one dog stool sample, whereas no parasite species were found in cat stool samples. The eggs of $T$. canis, Acanthocephala, T. leonina, Capillaria spp. were found in red fox stool samples. To the best of our knowledge, children's playgrounds were researched for the first time in terms of zoonotic helminth species in Sivas.
\end{abstract}

Keywords: Children's playgrounds, helminth, PCR, Sivas, zoonosis.

\section{Sivas ilinde çocuk oyun parklarında zoonotik helmintlerin araştırılması}

\begin{abstract}
Özet: İnsan toxocariasisi ABD Hastalık Kontrol ve Önleme Merkezi (CDC) tarafından göz ardı edilen bir paraziter hastalık olarak sınıflandırılmaktadır. Hastalık çocuklarda erişkinlere göre daha yaygındır. Çünkü çocuklar dışarıda oyun oynarken insan toxocariasis etiyolojik etkenleri olan T. canis ve T. cati yumurtalarına daha sık maruz kalmaktadır. Bu çalışmanın amacı Sivas'taki çocuk oyun parklarında helmint türlerinin varlığını mikroskobik ve moleküler teknikler kullanarak araştırmaktır. Bu amaçla Temmuz 2020 ve Temmuz 2021 tarihleri arasında 25 çocuk oyun parkından 84 kum numunesi alınmıştır. Ayrıca çocuk oyun parklarının içinden ve etrafından kedi, köpek ve kızı tilkilere ait 68 dışkı numunesi toplanmıştır. Bu çalışmada beş kum örneğinde Toxocara spp. yumurtası tespit edilmiştir. PZR sonuçlarına göre üç kum örneğinde $T$. cati, iki kum örneğinde T. canis tespit edilmiştir. Toxascaris leonina sadece bir köpek dışkı örneğinde tespit edilirken, kedi dışkı örneklerinde parazit türü bulunmamıştır. Kızıl tilki dışkı örneklerinde ise T. canis, Acanthocephala, T. leonina, Capillaria spp. yumurtaları bulunmuştur. Bildiğimiz kadarıyla Sivas'ta çocuk oyun parkları zoonotik helmint türleri bakımından ilk kez incelenmiştir.
\end{abstract}

Anahtar kelimeler: Çocuk oyun parkları, helmint, PZR, Sivas, zoonoz.

\section{Introduction}

Dogs and cats have lived together with humans since the domestication process and have become the most popular pet animals in the world. However, these animals are abandoned to the streets due to the difficulties faced by their owners such as caring and feeding. The number of these animals increases gradually in the cities, and because of this, public health is threatened by these animals (Robertson and Thompson 2002) since cats and dogs are the definitive hosts of different parasitic pathogens such as Toxocara canis and T. cati which are the etiological agents of human toxocariasis (Taylor et al. 2016).
Human toxocariasis is assessed to be one of the most important neglected parasitic diseases in the world by the Centers for Disease Control and Prevention (CDC 2020). The global seroprevalence of human toxocariasis was ranging from 1.6 to $92.8 \%$ (Smith and Noordin 2006). The disease is more prevalent in undeveloped or developing countries than developed countries, due to the high number of companion animals, lack of sanitary conditions, and lack of personal hygiene (Smith and Noordin 2006; Nooraldeen 2015).

Humans become infected with Toxocara spp. by ingestion of embryonated eggs from contaminated vegetables, soils, or direct contact with infected cats

Yazışma adresi / Correspondence: Ufuk Erol, Department of Parasitology, Faculty of Veterinary Medicine, University of Sivas Cumhuriyet, Sivas, Turkey E-mail: ufukerol@cumhuriyet.edu.tr 
or dogs, and consumption of infective stage larvae present in undercooked organs of paratenic hosts (Despommier 2003; Overgaauw and van Knapen 2013; Taylor et al. 2016). According to the researches, embryonated eggs are generally present in children's playgrounds contaminated with definitive host stool. Therefore, children's playgrounds are considered risky areas for human toxocariasis (Overgaauw and van Knapen 2013). Many different studies were conducted for the determination of Toxocara spp. in children's playgrounds in the world (Borecka and Gawor 2008; Nooraldeen 2015; Kleine et al. 2017; Bystrianska et al. 2019; Sadowska et al. 2019) and the determination of zoonotic helminth species in children's playgrounds in Turkey (Oge and Oge 2000; Gürel et al. 2005; AydenizözÖzkayhan 2006; Avcioglu and Burgu 2008; Avcioglu and Balkaya 2011; Bozkurt et al. 2012; Aydın 2020). To the best of our knowledge, there is no study on zoonotic helminth diseases in Sivas, although Sivas province has a lot of stray cats and dogs like any other city in Turkey. The present study aimed to determine the presence and distribution of potential zoonotic helminths eggs in children's playgrounds in Sivas province for the first time using microscopic techniques and species-specific PCR for identification of Toxocara spp. eggs.

\section{Material and Methods}

This research was performed in Sivas province, located in the Central Anatolia Region of Turkey. The average annual temperature of Sivas is $8.9^{\circ} \mathrm{C}$, and the average relative humidity is $65 \%$.

From July 2020 to July 2021, sand samples were taken from 25 children's playgrounds, 20 of which were from the city center, and five of which were from recreation areas. A total of 84 sand samples consisted of 60 sand samples collected from city center parks, and 24 sand samples collected from recreation areas. We also collected 68 stool samples belonging to cats ( $n: 19)$, dogs ( $n: 21)$, and red foxes (n:28) from and around children's playgrounds during the sampling period. Sand and stool samples were stored at $-80^{\circ} \mathrm{C}$ for seven days for inactivation of possible Echinococcus spp. eggs (Hofer et al. 2000).

Approximately $250 \mathrm{~g}$ sand samples were collected from $10 \mathrm{~cm}$ depth of ground surface into plastic bags from each children's playground. Sand samples were homogenized, and then a $50 \mathrm{~g}$ sample was examined in terms of helminth eggs. In the laboratory, sand samples were mixed with distilled water and $1 \mathrm{~mL}$ Tween-40. Homogenized material was vortexed for five minutes and filtered through a $250 \mu \mathrm{L}$ sieve to remove big particles. Out of $28 \mathrm{~mL}$ homogenized material was taken into a $50 \mathrm{~mL}$ falcon tube, and $20 \mathrm{~mL}$ distilled water was added. The material was centrifuged at $2500 \times \mathrm{rpm}$ for $3 \mathrm{~min}$. The supernatant was removed and the same volume of distilled water was added to the sediment. This procedure was repeated at least three times. Final sediment was transferred in a centrifuge tube to which saturated ZnSO4 (33\%, density:1.18) solution was added (Kazacos 1983; Avcioglu and Burgu, 2008; Taylor et al. 2016). The homogenized sample was centrifuged at $2500 \times$ rpm for 10 minutes. Samples were examined for helminth eggs under a light microscope using $10 \times$ and $40 \times$ objectives.

Stool samples were examined by using flotation and sedimentation methods as described in detail by Taylor et al. (2016), and Zajac et al. (2012), respectively.

Identification of helminth eggs was performed based on their morphological features such as shape, thickness, and color of the shell (Uga et al. 2000; Taylor et al. 2016).

\section{DNA Extraction from Toxocara spp. eggs}

The method of genomic DNA extraction from Toxocara spp. eggs was performed as described by Dinkel et al. (1998) with little modifications. Some modifications were as follows; Toxocara spp. eggs were put in a boiling water bath for one minute and then snap-frozen in a $-196^{\circ} \mathrm{C}$ liquid nitrogen for one minute. These procedures were repeated at least five times. Furthermore, Toxocara spp. eggs were incubated at $56^{\circ} \mathrm{C}$ for 4 hours with proteinase K (Cat No. P6556, Sigma-Aldrich ${ }^{\circledR}$, Israel). Total genomic DNA obtained from eggs was stored at $-20^{\circ} \mathrm{C}$ until use.

\section{Molecular Identification of Toxocara spp.}

The second internal transcribed spacer (ITS-2) of ribosomal DNA (rDNA) gene was amplified with species-specific primers in order for the discrimination of Toxocara spp. eggs obtained from sand and stool samples. Further information about primers is given in Table 1.

PCR amplification was performed in a total volume of $50 \mu \mathrm{L}$ using DNase-RNase-free sterile water (Cat No.: 129114, Qiagen ${ }^{\circledR}$, Germany), 10× PCR buffer (Thermo Scientific ${ }^{\mathrm{TM}}$, Lithuanian), $2.5 \mathrm{mM} \mathrm{MgCl}$ (25 mM) (Thermo Scientific ${ }^{\text {TM }}$, Lithuanian), $200 \mu \mathrm{M}$ of each dNTP (Cat. No.: DN021-1000, GeneDireX ${ }^{\circledR}$ ), $1.25 \mathrm{U}$ of Taq DNA polymerase (Cat. No.: EP0402, 
Thermo Scientific ${ }^{\mathrm{TM}}$, Lithuanian), $2 \mu \mathrm{L}(10 \mathrm{pmol} / \mu \mathrm{L})$ of each of the primers, and $5 \mu \mathrm{L}$ template DNA. The multiplex PCR conditions were as follows; $94^{\circ} \mathrm{C}$ for 5 min (initial denaturation), followed by 35 cycles of $94^{\circ} \mathrm{C}, 1 \mathrm{~min}$ (denaturation), $55^{\circ} \mathrm{C}, 1 \mathrm{~min}$ (annealing), $72^{\circ} \mathrm{C}, 1 \mathrm{~min}$ (extension), and a final extension of $72^{\circ} \mathrm{C}$ for $5 \mathrm{~min}$ (Li et al. 2007). Sterile deionized water was used as the negative control, and DNA of $T$. canis and $T$. cati which were obtained from adult nematodes present in our laboratory were used as the positive control in each PCR assay. About $10 \mu \mathrm{L}$ PCR product were loaded on $1.5 \% \mathrm{~W} / \mathrm{v}$ agarose gel, stained with ethidium bromide for screening specific band profile of $T$. canis ( 330 bp) and T. cati ( 660bp). All PCR steps were done in separate rooms to avoid cross-contamination.

Table 1. Primers used in the current research.

\begin{tabular}{lcccc}
\hline Species & Primer & Length of PCR product & Target Gene & References \\
\hline \multirow{2}{*}{ T. canis } & YY1 (5'-CGGTGAGCTATGCTGGTGTG-3') & $\sim 330 \mathrm{bp}$ & ITS-2 & Li et al. 2007 \\
\hline NC2 (5'-TTAGTTTCTTTTCCTCCGCT-3') & & ITS-2 & Li et al. 2007 \\
\hline
\end{tabular}

\section{Results}

Toxocara spp. eggs were detected in five of 25 (20.0\%) children's playgrounds. Toxocara spp. eggs were found in three (15.0\%) of 20 children's playgrounds located in the city center and in two
(40.0\%) of five children's playgrounds located in the recreation areas. Toxocara spp. eggs were detected in three of 60 sand samples (5.0\%) collected from the city center and in two of 24 sand samples (8.3\%) collected from recreation areas (Table 2).

Table 2. Distribution of helminths eggs detected in the sand and stool samples.

\begin{tabular}{|c|c|c|c|c|c|c|c|}
\hline Samples & $\begin{array}{c}\text { Number of } \\
\text { Samples }\end{array}$ & $\begin{array}{c}\text { Number of } \\
\text { Positive Samples }\end{array}$ & T. canis* & T. cati* & T. leonina & Capillaria spp. & Acanthoceplaha \\
\hline $\begin{array}{l}\text { Sand samples from } \\
\text { the city canter }\end{array}$ & 60 & 3 & 1 & 2 & - & - & - \\
\hline $\begin{array}{l}\text { Sand samples from } \\
\text { the recreation areas }\end{array}$ & 24 & 2 & 1 & 1 & - & - & - \\
\hline Dog stool samples & 21 & 1 & - & - & 1 & - & - \\
\hline $\begin{array}{l}\text { Red fox stool } \\
\text { samples }\end{array}$ & 28 & 13 & 9 & - & 2 & 1 & 3 \\
\hline Cat stool samples & 19 & - & - & - & & - & - \\
\hline
\end{tabular}

* Species identification of T. canis and T. cati eggs were performed with PCR.

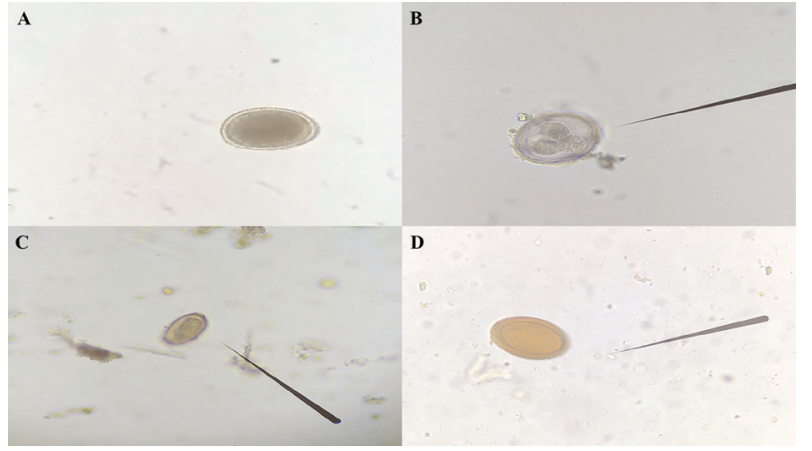

Figure 1. The eggs identified in the present study. A. Toxocara spp. eggs, B. T. leonina eggs, C. Capillaria spp. eggs, D. Acanthocephala eggs.
Toxocara spp. (9/28), T. leonina (2/28), Capillaria spp. (1/28), and Acanthocepla (3/28) eggs in fox stool samples; Toxascaris leonina in one dog's stool sample (Figure 1), and no helminths egg or larvae in the cat stool samples were detected during the microscopic examination.

The species-specific PCR assay revealed that T. cati was found in three sand samples (two from the city center and one from the recreation areas), whereas $T$. canis was detected in two sand samples (one from the city center and one from the recreation areas). Furthermore, according to the PCR results, all Toxocara spp. eggs obtained from nine different red foxes stool samples were identified as T. canis (Figure 2). 


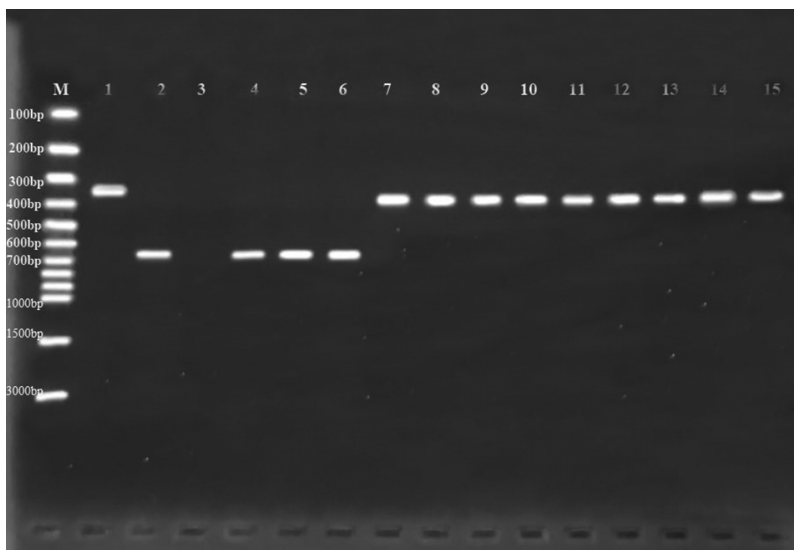

Figure 2. Agarose-gel electrophoresis of Toxocara spp. specific polymerase chain reaction. M. Marker, Lane 1. T. canis positive control DNA ( 330 bp), Lane 2. T. cati positive control DNA ( 660 bp), Lane 3. Negative control distilled water, Lane 4-6. T. cati positive DNA, Lane 7-15. T. canis positive DNA.

\section{Discussion and Conclusion}

Toxocariasis is a parasitic disease caused by the infective stage larvae of $T$. canis and $T$. cati in paratenic hosts such as humans. Humans get infected with Toxocara spp. after ingestion of embryonated eggs or infective stage larvae (Despommier 2003). After ingestion, larvae are released into the intestines of humans and do not develop to the adult stage. These infective stage larvae migrate to different internal organs and can cause visceral and ocular larvae migrants, covert toxocariasis, and neurotoxocarosis in humans (Overgaauw 1997; Despommier 2003). Definitive hosts such as dogs, cats, and wild carnivores can shed Toxocara spp. eggs via feces to the environment and cause severe contamination with Toxocara spp. in a short time. The reasons are as follows; i.) female adult parasites might produce up to 200,000 eggs in one day, ii.) these eggs develop within two weeks under optimal environmental conditions and reach the infective stage for paratenic (e.g. human and small rodent) or definitive hosts, iii.) Toxocara spp. eggs have a sticky and thick shell, these features protect eggs from harsh environmental conditions and remain infective for hosts for months (Overgaauw 1997; Despommier 2003; Overgaauw and van Knapen 2013; Traversa et al. 2014). For these reasons, human health is threatened by T. canis and T. cati, and eggs of these nematodes are mostly present in children's playgrounds (Overgaauw 1997; Despommier 2003). The aim of this research was to determine the presence and distribution of zoonotic helminths eggs in the chil- dren's playgrounds in Sivas province using microscopic techniques and to identify Toxocara spp. to species level using PCR.

Human toxocariasis is more prevalent in children than adults (Overgaauw and van Knapen 2013). This situation could be related to that children are more exposed to $T$. canis and $T$. cati eggs while playing in children's playgrounds (Overgaauw 1997; Despommier 2003). Because the definitive hosts of these parasites can easily access public parks and children's playgrounds, these areas might be more contaminated with Toxocara spp. eggs than other areas (Sadowska et al. 2017). For this reason, many different studies have been conducted to determine the presence and distribution of Toxocara spp. egg in children's playgrounds (Avcioglu and Burgu 2008; Borecka and Gawor 2008; Nooraldeen 2015; Sadowska et al. 2017; Bystrianska et al. 2019; Aydın 2020). In a meta-analyses study, the global prevalence of Toxocara spp. was determined as $21 \%$, while $16 \%$ in Turkey (Fakhri et al. 2018).

The flotation techniques have been used in many studies for the detection of Toxocara spp. eggs in sand samples. Because these techniques are cheaper and faster compared to molecular diagnostic methods like PCR (Oge and Oge 2000; Aydenizöz- Özkayhan 2006; Avcioglu and Balkaya 2011; Nooraldeen 2015; Bystrianska et al. 2019; Aydın 2020). However, flotation techniques are not eligible for the discrimination of $T$. canis and $T$. cati eggs since the eggs of these nematodes have similar morphologic features (Uga et al. 2000). Consequently, researchers have used species-specific PCR to recognize $T$. canis and $T$. cati eggs in contaminated materials (Borecka and Gawor 2008; Bozkurt et al. 2012; Durant et al. 2012). In this study, sand and stool samples were screened with both microscopic (flotation) and molecular (species-specific $\mathrm{PCR}$ ) techniques.

In Turkey, many different studies were performed for the assessment of the presence of Toxocara spp. eggs in children's playgrounds using flotation (Güçlü and Aydenizöz 1998; Oge and Oge 2000; Toparlak et al. 2002; Aydenizöz-Özkayhan 2006) but there is only one study used PCR (Bozkurt et al. 2012). In these studies, Toxocara spp. eggs were found in children's playground in different prevalences such as $8.33 \%$ in İstanbul (Toparlak et al. 2002), 15.05-30.6\% in Ankara (Oge and Oge 2000; Avcioglu and Burgu 2008), 15.60\% in Kırıkkale (Aydenizöz-Özkayhan 2006), 18.91\% in Aydın (Gürel et al. 2005), 4.16\% in Konya (Güçlü and Aydenizöz 1998), 25.97\% in Van (Ayaz et al. 2003), 10\% in Kü- 
tahya (Akdemir 2010), 14.01\% in Erzurum (Avcioglu and Balkaya 2011), and $25.53 \%$ in Karaman (Aydın 2020), respectively. Toxocara spp. eggs were detected in $7.3 \%$ of the children's playgrounds in a study conducted with PCR in Kayseri (Bozkurt et al. 2012). With the current study, we detected Toxocara spp. eggs in $5.9 \%$ of sand samples $(5 / 84)$. This result showed that our result was only higher than in Konya (Güçlü and Aydenizöz 1998) and lower than the other studies performed in Turkey. The prevalence of Toxocara spp. in sand samples may change according to the climatic conditions of sampling areas, numbers of companion animals (cats or dogs), and activities of the municipalities (Fakhri et al. 2018; Aydın 2020). Toxocara species need high temperatures $\left(25-30^{\circ} \mathrm{C}\right)$ and humidity to complete their embryonic development in the environment (Anderson 2000). The average annual temperature of Sivas is $+8.9^{\circ} \mathrm{C}$. This low temperature in Sivas province may not eligible for Toxocara spp. to complete their development. For this reason, a lower amount of Toxocara spp. eggs can reach the infective stage in Sivas compared to the other cities that have moderate climatic conditions. As a consequence of this, a lower amount of definitive host is exposed to the infective Toxocara eggs. It is also very important that children's playgrounds are surrounded with fences by municipalities since it will be more difficult for the definitive hosts of $T$. canis and $T$. cati to enter the fenced parks and these playgrounds (Avcioglu and Balkaya 2011). In Sivas province, most of the children's playgrounds are fenced. We speculate that thanks to the harsh climatic conditions of Sivas province and fenced children's playgrounds, Toxocara spp. was found in low prevalence in sand samples in our study.

In the current study, a species-specific PCR assay was used for the discrimination of Toxocara spp. eggs obtained from sand and stool samples. For the identification of Toxocara spp. eggs with PCR, the ITS-2 gene has been used by researchers. This gene can be successfully used in the recognition of Toxocara species such as T. canis, T. cati, T. vitulorum, and T. malaysiensis (Li et al. 2007; Borecka and Gawor 2008; Bozkurt et al. 2012; Durant et al. 2012). For this reason, we used the ITS-2 gene in this study. According to the PCR results in the present study, $T$. cati was found in three sand samples, whereas T. canis was detected in two sand samples. Furthermore, T. canis was found in nine red fox stool samples. PCR results revealed that red fox is responsible for the contamination of children's playgrounds with Toxocara eggs.
The red fox is the most widespread wild mammal in Turkey (Ambarli et al. 2016). This animal is known to be the definitive host of $T$. canis in the sylvatic cycle (Taylor et al. 2016). For this reason, the red fox plays an important role in the contamination of the environment with $T$. canis eggs. In the current study, the rate of $T$. canis eggs was found at $32.1 \%$ $(9 / 28)$ with PCR assay in red fox stool samples. Moreover, T. leonina (2/28), Capillaria spp. (1/28), and Acanthocephala (3/28) eggs were detected in red fox stool samples. This study revealed that red fox is also responsible for environmental contamination with zoonotic helminth eggs. Therefore, authorities should take precautions to prevent access of red foxes to children's playgrounds to protect human health.

In conclusion, this is the first survey of Toxocara spp. in play gardens from Sivas. As a result of this study, both $T$. canis and T. cati eggs were detected in sand samples. These results revealed that children playing in contaminated play gardens could be at risk in terms of human toxocariasis. Human toxocariasis is one of the most dangerous parasitic diseases in Turkey. This dangerous disease can also be preventable with the precautions like eliminating infection in definitive hosts using anthelmintic drugs, educating pet owners, and preventing access of definitive hosts to children's playgrounds.

Conflict of Interest: The authors declare that they have no conflicts.

Acknowledgment: This work is supported by the Scientific Research Project Fund of Sivas Cumhuriyet University under the project number V-107.

Ethical Statement: This study does not present any ethical concerns.

\section{References}

Akdemir C. (2010) Visceral larva migrans among children in Kütahya (Turkey) and an evolution of playgrounds for T. canis eggs. Turk J Pediatr. 52, 158-162.

Ambarli H, Ertürk A, Soyumert A. (2016) Current status, distribution, and conservation of brown bear (Ursidae) and wild canids (gray wolf, golden jackal, and red fox; Canidae) in Turkey. Turk J Zool. 40, 944-956.

Anderson RC. (2000) Nematode parasites of vertebrates: their development and transmission. Second edition. Cabi Publishing, London.

Avcioglu H, Burgu A. (2008) Seasonal prevalence of Toxocara ova in soil samples from public parks in Ankara, Turkey. Vector Borne Zoonotic Dis. 8, 345-350.

Avcioglu H, Balkaya I. (2011) The relationship of public park accessibility to dogs to the presence of Toxocara species ova in the soil. Vector Borne Zoonotic Dis. 11, 177-180. 
Ayaz E, Yaman M, Gül A. (2003) Prevalence of Toxocara spp. eggs in soil of public parks in Van, Turkey. Indian Vet J. 80, 574-576.

Aydenizöz-Özkayhan M. (2006) Soil contamination with ascarid eggs in playgrounds in Kirikkale, Turkey. J Helminthol. 80, 15-18.

Aydın MF. (2020) Presence of Toxocara spp. and other zoonotic parasites Ova in children's playground in Karaman, Turkey. Turkiye Parazitol Derg. 44, 17-20.

Borecka A, Gawor J. (2008) Modification of gDNA extraction from soil for PCR designed for the routine examination of soil samples contaminated with Toxocara spp. eggs. J Helminthol. 82, 119-122.

Bozkurt Ö, Yildirim A, İnci A. (2012) Kayseri ili parklarında bulunan oyun alanlarının Askarit türleri ile kontaminasyonunun parazitolojik ve moleküler yöntemlerle araştırılması. Kafkas Univ Vet Fak Derg. 18, A175-180.

Bystrianska J, Papajová I, Šoltys J, Sasáková N. (2019) Contamination of sandpits with soil-transmitted helminths eggs in an urban environment. Folia Vet. 63, 60-63.

Centers for Disease Control and Prevention. (2020) Erişim adresi: https://www.cdc.gov/parasites/toxocariasis/, Erişim tarihi: 24.08.2021.

Despommier D. (2003) Toxocariasis: clinical aspects, epidemiology, medical ecology, and molecular aspects. Clin Microbiol Rev. $16,265-272$.

Dinkel A, von Nickisch-Rosenegk M, Bilger B, Merli M, Lucius R, Romig T. (1998) Detection of Echinococcus multilocularis in the definitive host: coprodiagnosis by PCR as an alternative to necropsy. J Clin Microbiol. 36, 1871-1876.

Durant JF, Irenge LM, Fogt-Wyrwas R, Dumont C, Doucet JP, Mignon B, Losson B, Gala JL. (2012) Duplex quantitative real-time PCR assay for the detection and discrimination of the eggs of Toxocara canis and Toxocara cati (Nematoda, Ascaridoidea) in soil and fecal samples. Parasit Vectors. 5, 1-9.

Fakhri Y, Gasser RB, Rostami A, Fan CK, Ghasemi SM, Javanian M, Bayani M, Armoon B, Moradi B. (2018) Toxocara eggs in public places worldwide-A systematic review and metaanalysis. Environ Pollut. 242, 1467-1475.

Güçlü F, Aydenizoz M. (1998) Çocuk parklarındaki kumların köpek ve kedi helminti yumurtaları ile kontaminasyonunun tesbiti. Turkiye Parazitol Derg. 23, 24-27.

Gürel FS, Ertuğ S, Okyay P. (2005) Prevalence of Toxocara spp. eggs in public parks of the city of Aydın, Turkey. Turkiye Parazitol Derg. 29, 177-179.

Hofer S, Gloor S, Müller U, Mathis A, Hegglin D, Deplazes P. (2000) High prevalence of Echinococcus multilocularis in urban red foxes (Vulpes vulpes) and voles (Arvicola terrestris) in the city of Zürich, Switzerland. Parasitology. 120, 135-142.

Kazacos KR. (1983) Improved method for recovering ascarid and other helminth eggs from soil associated with epizootics and during survey studies. Am J Vet Res. 44, 896-900.

Kleine A, Springer A, Strube C. (2017) Seasonal variation in the prevalence of Toxocara eggs on children's playgrounds in the city of Hanover, Germany. Parasit Vectors. 10, 1-8.

Li MW, Lin RQ, Chen HH. (2007) PCR tools for the verification of the specific identity of ascaridoid nematodes from dogs and cats. Mol Cell Probes. 21, 349-354.

Nooraldeen K. (2015) Contamination of public squares and parks with parasites in Erbil city, Iraq. Ann Agric Environ Med. 22, 418-420.

Oge S, Oge H. (2000) Prevalence of Toxocara spp. eggs in the soil of public parks in Ankara, Turkey. Dtsch Tierarztl Wochenschr. 107, 72-75.

Overgaauw PAM. (1997) Aspects of Toxocara epidemiology: human Toxocarosis. Crit Rev Microbiol. 23, 215-231.

Overgaauw PA, van Knapen F. (2013) Veterinary and public health aspects of Toxocara spp. Vet Parasitol. 193, 398-403.

Robertson ID, Thompson RC. (2002) Enteric parasitic zoonoses of domesticated dogs and cats. Microbes Infect. 4, 867-873.

Sadowska N, Tomza-Marciniak A, Juszczak M. (2019) Soil contamination with geohelminths in children's play areas in Szczecin, Poland. Ann Parasitol. 65, 65-70.

Smith H, Noordin R. (2006) Diagnostic Limitations and Future Trends in Serodiagnosis of Human Toxocariasis. Holland $\mathrm{CV}$, Smith HV. eds. Toxocara the enigmatic parasite, CABI Publishing, Cambridge. p.89-112.

Taylor MA, Coop RL, Wall RL. (2016) Veterinary Parasitology, Fourth edition. Blackwell Publishing, Oxford.

Toparlak M, Gargili A, Tüzer E, Keleş V, Esatgil MU, Çetinkaya H. (2002) Contamination of children's playground sandpits with Toxocara eggs in İstanbul, Turkey. Turk J Vet Anim Sci. 26, 317-320.

Traversa D, di Regalbono AF, Di Cesare A, La Torre F, Drake J, Pietrobelli M. (2014) Environmental contamination by canine geohelminths. Parasit Vectors. 7, 1-9.

Uga S, Matsuo J, Kimura D, Rai SK, Koshino Y, Igarashi K. (2000) Differentiation of Toxocara canis and T. cati eggs by light and scanning electron microscopy. Vet Parasitol. 2000, 92, 287294.

Zajac AM, Conboy GA, Greiner EC, Smith SA, Snowden KF. (2012) Fecal Examination for the Diagnosis of Parasitism. Zajac AM, Conboy GA. eds. in Veterinary Clinical Parasitology, Eighth edition. John Wiley and Sons, Sussex. p.3-171. 